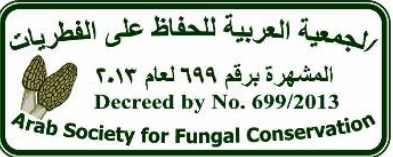

Contents lists available at Egyptian Knowledge Bank

Microbial Biosystems

Journal homepage: http://mb.journals.ekb.eg/

\title{
Jean Mouchacca: The mycologist and Ramesses II's mummy
}

\section{Abdel-Azeem MA}

Pharmacognosy Department, Faculty of Pharmacy, Suez Canal University, Ismaïlia 41522, Egypt.

Published by Arab Society for Fungal Conservation

Jean Mouchacca, the Egyptian Armenian mycologist, born in Alexandria of Egypt in $29^{\text {th }}$ June (1939), from Armenian parents; established in the Nile Valley early $20^{\text {th }}$ century.

He received his primary education in local religious French schools, by (1956); he got his National secondary school certificate, scientific section. By (1961), he received his Bachelor degree of Science in Chemistry and Botany from Faculty of Science, Ain-Shams University, Cairo with a total grade of very good. After getting his bachelor degree, he realized his interest into science so he travelled to Paris University to get his first postgraduate diploma in plant biology, section tropical botany "Diplôme d'Etudes Approfondies" by (1968).

In (1982), he received his doctoral degree of science "Doctorat d'Etat ès Sciences Naturelles" from the National Museum of Natural History and University Pierre \& Marie Curie (Paris VI), for his thesis entitled, "Etude analytique de la mycoflore de quelques régions arides de l'Egypte" and an overall grade of highly honourable with congratulations of the Jury.

Mouchacca started his professional carrier as a demonstrator in Botany Department, Faculty of Science, Cairo University in (1961), then in early (1963), he worked as a Chemist in Société MISR pour LA RAYONNE, Alexandria, Egypt. By (1965), he started his job as a research assistant in the Botany Department, Desert Institute, Egyptian Ministry of Scientific Research.

In (1976), he received a technical cooperation scholarship from the French government for postgraduate studies. Starting from (1968), he started to work as Research Scholar, Laboratoire de Cryptogamie, National Museum of Natural History (NMNH), Paris, France.

In (1974), he was appointed as temporary Assistant Research of University, and from (1979), a Permanent Assistant Research. From (1988), he was nominated as Associate Professor of University, and in (1993), he was

* Corresponding author

E-mail address: els_portsaid@hotmail.com (Mohamed Abdel-Azeem) raised to the $1^{\text {st }}$ class. From (1999), he was appointed as Associate Professor, High Grade till retirement in (2007). Present situation: Honorary Associate Professor, NMNH.

Mouchacca was an active member in several scientific societies such as; Société Mycologique de France (196898), Paleopathology Association, Detroit (1977-80), Société Française de Mycologie Médicale (1979-1989), British Mycological Society, London (1981-2000), Société Française de Phytopathologie (1985-1995), and Société Française de Systématique (1990-2000).

In addition, Mouchacca has participated in several scientific projects funded by the French National Centre of Scientific Research (NCSR), focusing his research in the era of cryptogams.

$\mathrm{He}$ was elected as a member of the Executive Committee, International Mycological Association (IMA), session (1990-1994). He was elected as a member, out of six members, in the Commission of Fungi, organisation for the phytotaxonomic studies of the Mediterranean region (OPTIMA), sessions (1998-2001) and (2001-2004). He is the founder and a member of the Organising Committee, and also of the French Local Committee of the First International Workshop on Ascomycetes Systematics. Mouchacca was the curator of the Mycological Herbarium (Fungarium), Laboratoire de Cryptogamie, NMNH, (1975-1985).

Jean was elected as a member in the National Council of the French Universities, Section 67 'Biology of Populations and Ecology', session (1992-1995), reelected (1995-98) and (1999-2002). Additionally, he was elected as a member of the Commission of Specialists, National Museum of Natural History (NMNH), Section 67, session (1992-1995), and then re-elected as VicePresident, session (1995-1998).

Mouchacca was in charge of the research investigations on the 'Biodegradation of Ramesses II mummy by Fungi', during the operation 'Salvation of the 
mummified body of this Pharaoh', Paris, (1976-1977).

Finding the cause of the deterioration and arresting it were imperatives in the study. From among the wrappings, minute samples of the mummy' chest and hair were taken for analysis. Mouchacca succeeded in identifying the destructive organism - a fungus with the splendid name Daedalea biennis (Bull.) Fr.

Abdel-Azeem (2010), in his study entitled, "The history, fungal biodiversity, conservation, and future perspectives for mycology in Egypt", he documented the role of Jean Mouchacca and his colleagues in (Laboratoire de Cryptogamie, Muséum National d'Histoire Naturelle, Paris), in describing 18 new species that represent $17.1 \%$ of the total novel taxa in Egypt.

In (2012), Ahmed Abdel-Azeem, Suez Canal
University, Egypt with Mouchacca and 19 mycologists, have founded the Arab Society for Fungal Conservation.

The Arab Society for Fungal Conservation aimed to support efforts to create a network of associations working in the field of fungal conservation at various levels (local and international) and raise the level of awareness among scientists in the Arab world to promote the protection of wildlife and biodiversity of fungi and microorganisms. Mouchacca published around 100 publications, reviewed 52 books, went for 30 scientific missions and attended 42 scientific meetings with several inclusive lectures. For more information concerning Mouchacca list of publication please check the supplementary materials.

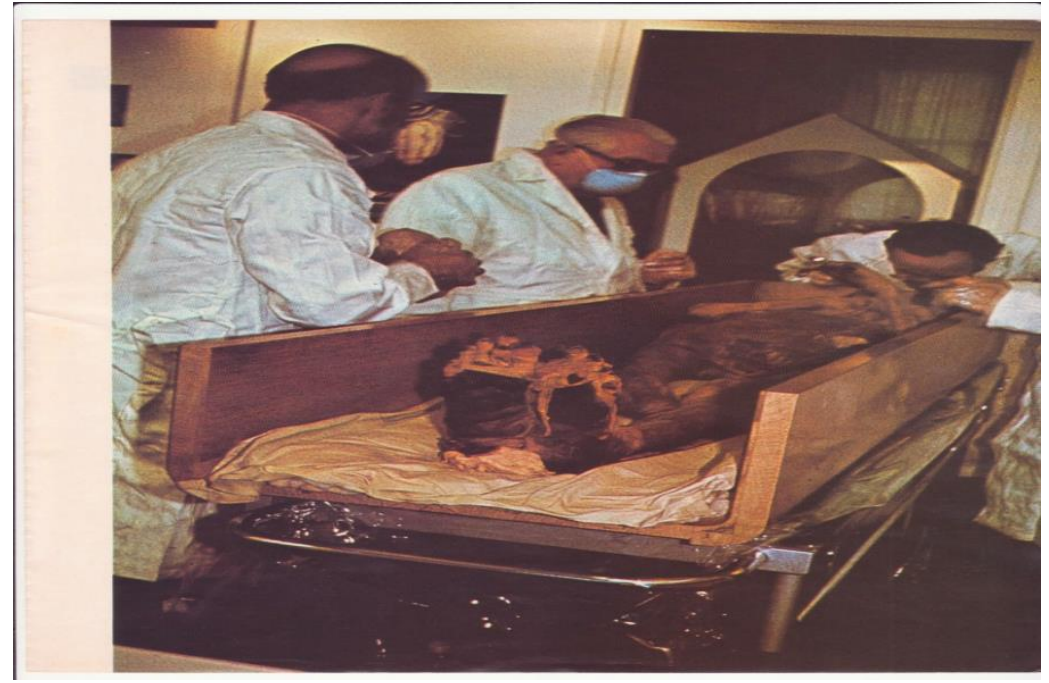

Mouchacca J. during the examination of the mummified body of Ramesses II in Paris (1976-1977)

In (2017), Mouchacca messaged Prof. Ahmed M. Abdel-Azeem during the celebration of the $2^{\text {nd }}$ national fungus day of Egypt; "Dear friends and colleagues in Ismailia Suez Canal University, Alf Alf Mabrouk for the second celebration of the Egyptian Fungus Day on $20^{\text {th }}$ February (2017), a unique worldwide event at the initiative of the Arab Society for Fungal Conservation, recently established in (2013). In the Arab World, Egypt is a leading country in the field of mycology thanks to the marked progress achieved by the pioneer mycologists in the last decades. This position is however presently fragile, which needs to be markedly consolidated by a new generation of enthusiastic young mycologists exploring the particular fungal communities of the Nile Valley and of its wide surrounding arid zones, a prelude for sound conservation measures. I take this occasion to forward my best wishes for the development of the Arab Society for Fungal Conservation and for a successful celebration of this second Egyptian Fungus Day. God bless you.

\section{A message from Mouchacca}

"In relation with my mycological pathway, I take this opportunity to underline my sincere gratitude to the late Prof. Ahmed Ibrahim Naguib, former head of the Microbiology Section of the Desert Institute who initiated my arrival at the French NMNH, and to my close, also late, colleague Mohamed Refaat Rabie. A special mention is also forwarded about the marked friendly atmosphere that prevailed among the novel group of young researchers, freshly nominated at the onset of the year 1965 at this Institute." 


\section{Further readings}

Abdel-Azeem AM (2010) The history, fungal biodiversity, conservation, and future perspectives for mycology in Egypt. IMA Fungus 1(2):123-142.

Mouchacca J (2005) Champignons thermophiles: Evolution des concepts taxonomiques. In J du Rés de Mycol, Université de Provence et de la Méditerranée, Marseille, 2-4 février 2005. Résumé de conférence, p. AC 51.

Mouchacca J (2007) Heat-tolerant fungi and applied research: more data on pseudothermophilic taxa. Crypt Mycol 28:91-106.

Mouchacca J (2007) Heat-tolerant fungi and applied research: On the taxonomic position of some overlooked thermophilic fungi. Crypt Mycol 28:215-223.

Mouchacca J (2007) Heat-tolerant fungi and applied research: Addition to the previously treated group of strictly thermotolerant species. Worl J Micr Biot 23:1755-1770.

Mouchacca J (2008) Novel fungal taxa from the arid Middle East region introduced prior to the year 1940. I - Nonlichenized Ascomycetes. Crypt Mycol 29:365-388.

Mouchacca J (2009) Novel fungal taxa from the arid Middle East region introduced prior to the year 1940. II Anamorphic Fungi: Hyphomycetes. Crypt Mycol 30:199-222.

Mouchacca J (2009) Novel fungal taxa from the arid Middle East region introduced prior to the year 1940. III. Anamorphic Fungi - Coelomycetes. Crypt Mycol 30:377-403.

Mouchacca J (2010) Mycobiota of the arid Middle East: Biodiversity of novel fungal taxa introduced from 19402000. In the First International Conference on Basic and Applied Mycology, 9-11 March 2010, AUMC, Assiut University, Assiut, Egypt, Book of Abstracts, Lecture Abstract, p. 33.

Mouchacca J and Dennetiere B (2013) -P. Hennings (1898) Fungi centro-africani: species collected by G. Schweinfurth in what is now the Republic of South Sudan. A revisit. Mycos 4 (3):496-518.

Mouchacca J (2016) Mycological discoveries in the Middle East region in the second part of the last century. Micro Biosys 1(1):1-39.

\begin{tabular}{l}
\hline ARTICLE INFO \\
\hline Article history \\
Received 8 June 2020 \\
Received revised 15 June 2020 \\
Accepted 29 June 2020 \\
Available online 1 July 2020 \\
O) Abdel-Azeem 2020 \\
Corresponding Editor: \\
Darwish AG, Balbool BA, Abdel-Azeem AM \\
\hline
\end{tabular}

